\title{
The Effects of Jigsaw Learning on Students' Attitudes in a Vietnamese Higher Education Classroom
}

\author{
Van Dat Tran (Corresponding author) \\ Faculty of Education, La Trobe University, Australia \\ Melbourne (Bundoora), Vic 3086, Australia \\ Tel: 61-3-9479-2611Ｅ-mail: v2tran@students.latrobe.edu.au \\ Ramon (Rom) Lewis \\ Faculty of Education, La Trobe University, Australia \\ Melbourne (Bundoora), Vic 3086, Australia \\ Tel: 61-3-9479-2611Ｅ-mail: r.lewis@latrobe.edu.au
}

Received: April 25, 2012

Accepted: May 18, 2012

Online Published: June 6, 2012

doi:10.5430/ijhe.v1n2p9

URL: http://dx.doi.org/10.5430/ijhe.v1n2p9

The project was conducted after receiving ethics approval from the Education Faculty Human Ethics Committee (R051/09), La Trobe University, and the Vice Rector of An Giang University.

\begin{abstract}
As a part of an experimental study on the effects of jigsaw learning on Vietnamese tertiary students' achievement and knowledge retention, students' attitudes towards six weeks of this kind of instruction were assessed. As noted in our previous report, students in the experimental group $(\mathrm{N}=40)$, who perceived their instruction as more cooperative and more student-centered, had significantly greater improvement on both achievement and retention measures than did the students in the control group $(\mathrm{N}=40)$. This paper furthers that analysis by examining students' attitudes towards learning via jigsaw grouping. The results indicate that in general students in the experimental group appreciated most working with others and getting help, discussing and sharing information and teaching others, and they enjoyed the jigsaw context. The qualitative findings of this study enrich understanding of how and why jigsaw learning contributed to the Vietnamese students' higher academic achievement and knowledge retention.
\end{abstract}

Keywords: Cooperative learning, Jigsaw learning, Learning Environment, Attitudes

\section{Introduction}

Cooperative learning, one kind of student-centered learning approach, has been documented throughout the literature as effective in helping students obtain practical learning skills, abilities for effective communication and proficiency in term of understanding knowledge, and it promotes positive student attitudes towards their own learning (Johnson \& Johnson, 2008; Slavin, 2011). In general, in Vietnamese higher education institutions (VHEI), lecture-based teaching is commonly employed (Harman \& Nguyen, 2010). Thus, the need to explore more modern and possibly more effective approaches towards teaching and learning has been identified as important (MOET, 2009). Recently, there have been efforts to implement student-centered approaches in an attempt to provide students with an interactive approach, to try and make the learning environment more stimulating. Although there is a view that the learning styles of students are determined by their cultures (Neuman \& Bekerman, 2000), the benefits of cooperative learning in western contexts reported in literature suggest that this kind of learning may not be culturally but contextually-based. In the traditional learning setting the majority of interactions are teacher-student. This can create a competitive environment and produce a passive attitude toward learning as students vie for the teacher's approval (Killen, 2007; Harman \& Nguyen, 2010). One alternative teaching method to lecture-based teaching is jigsaw grouping, a kind of cooperative learning method. This approach has been claimed to minimize the competitiveness in the learning environment by encouraging students to work together. In addition it is claimed to promote more positive student attitudes toward their own learning, enhance more positive relationships between participants, 
develop self-esteem and cohesiveness, and improve learning skills (Johnson \& Johnson, 2005; Sahin, 2010).

\section{Review of Literature}

Cooperative learning comprises "instructional methods in which teachers organize students into small groups, which then work together to help one another learn academic content" (Slavin, 2011, p.344). Jigsaw learning, one kind of cooperative learning method developed by Aronson, Blaney, Stepan, Sikes \& Snapp (1978), helps students break learning materials into manageable learning pieces, and then has students teach others the piece they have mastered, consequently combining these pieces into one whole. Jigsaw learning is based on the perspective that each student will first become "an expert" in a small part of the whole learning material, and then teach other students in his group this part of the material.

\subsection{Basic elements of Cooperative Learning}

Cooperative learning consists of five basic elements: positive interdependence, promotive interaction, individual accountability, teaching of interpersonal and social skills and quality of group processing (Johnson \& Johnson, 2008). The first element is positive interdependence. Positive interdependence means that in cooperative learning situations students are required to work together as a cohesive group to achieve shared learning objectives (Yager, 2000; Jensen, Moore \& Hatch, 2002). Positive interdependence may be facilitated through having students occupy complementary roles (Thomas 1957), through the provision of group contingencies (Skinner 1968), and by dividing information into separate components (Aronson et al. 1978) or division of labor (Knight \& Bohlmeyer, 1990). The second is promotive interaction. Promotive interaction occurs as individuals facilitate each other's efforts to accomplish the group's shared goals. As part of cooperative learning condition students are required to interact verbally with one another on learning tasks (Johnson \& Johnson, 2008), exchange opinions, explain things, teach others and present their understanding (Ballantine \& Larres, 2007). To construct promotive interaction, groups should be small when students begin learning together to help them develop learning skills (Slavin, 2011). The third element of cooperative learning is individual accountability. Individual responsibility means that students ask for assistance, do their best work, present their ideas, learn as much as possible, take their tasks seriously, help the group operate well, and take care of one another (Johnson, 2009). Individual accountability may be enhanced by keeping the size of the group small (Johnson, 2003). When groups are small, group members tend to communicate more frequently, which increases the amount of information utilized in arriving at a decision (Johnson \& Johnson, 2002). The fourth element is interpersonal and social skills. In reality students cannot work effectively if socially unskilled students are arranged into one group (Slavin, 1996). To achieve mutual goals students must: (a) get to know and trust each other; (b) communicate accurately and unambiguously; (c) accept and support each other; and (d) resolve conflicts constructively (Johnson \& Johnson 2006). When participants are more socially skilled, the achievement and productivity in cooperative groups tends to be higher (Johnson \& Johnson, 2008). The final element of cooperative learning is group processing. Group processing helps improve the effectiveness of the members in contributing to the shared efforts to achieve the group's goals, via reflection on the learning process (Yamarik, 2007). Reflection helps students decide which action is practical and which action is not practical, and which group processing should or should not be continued if there are problems existing within the group (Jensen et al., 2002). Evaluating interaction among group members, examining the group's tasks, giving feedback, and celebrating the presentation of the small group and the entire class may be effective ways of constructing group processing (Johnson \& Johnson, 1999). If these basic elements exist in cooperative learning groups, students achieve better, demonstrate superior learning skills (Johnson \& Johnson, 2008), and experience more positive relationships among group members, and between students and the teacher, and more positive self-esteem and attitudes toward the subject area (Slavin, 2011).

\subsection{Students' Perception of Cooperative Learning}

\subsubsection{Social support and positive relationships}

The results of several recent studies (Johnson \& Johnson, 2005; Johnson \& Johnson 2006; Bertucci, Conte, Johnson, \& Johnson, 2010) show that in cooperative learning situations, students provide more social support, both personally and academically, than students in competitive (effect size $=0.62$ ) or individualistic (effect size $=0.70$ ) situations. Social support has been shown to promote more positive relationships among participants than does either a competitive learning environment (effect size $=0.67)$ or individualistic learning (effect size $=0.60)($ Johnson \& Johnson, 2005). Such positive relationships result in an increase in motivation and persistence in working toward the shared goals, as well as more satisfaction, commitment to group goals, productivity and personal responsibility for achievement (Johnson \& Johnson, 2006; Slavin, 2011). The learning atmosphere of classrooms is likely to be associated with the educational policy and values of schools (Sharan \& Yaakobi, 1981), but cooperative learning results in positive social relationships among participants (learners and teachers); and expands the circle of 
companionship among the students (Kilic, 2009; Maceiras, Cancela, Urrejola \& Sanchez, 2010).

\subsubsection{Positive attitudes toward the learning process}

Cooperative learning has been shown to promote more positive attitudes of students toward their own learning than do competitive (effect size $=0.57$ ) or individualistic learning environments (effect size $=0.42$ ) because students work together for shared goals (Johnson \& Johnson, 2005). For example, in a six-week experimental study in a secondary school in America, Whicker, Bol \& Nunnery (1997) claim that the responses of most students in cooperative learning groups were favorable. Similarly, Vaughan (2002) suggests that students in the Student Teams Achievement Divisions (STAD) group had positive attitudes toward mathematics after STAD was implemented. These results were supported by previous research studies (Johnson \& Johnson, 1989; Mulryan, 1994; Cavalier, Klein, \& Cavalier, 1995; Nhu-Le, 1999) which showed a strong relationship between cooperative learning methods and the greater positive attitudes of students toward their own learning. For example, Nhu-Le (1999) reported the effects of cooperative learning on tertiary students' attitudes toward chemistry in Vietnam. The results showed that students liked working in cooperative learning groups, exchanging information and knowledge, working together, and assisting one another. Similarly, Mulryan (1994) and Mengeluo \& Xiaoling (2010) investigated students' attitudes and showed that in cooperative situations, students believed that their teachers paid more attention to their feelings. Students also noted that their peers liked to help one another and they were more motivated to learn. Overall, cooperative learning appears to lead to a greater affective perception of others, more positive attitudes, and increased humanity. Recently, several other researchers (Le, 2010; Thanh-Pham, 2010a\&b) investigated students' attitudes toward cooperative learning, and their attitudes toward subject matter in the Vietnamese setting of higher education. The results of these studies indicate that students working in cooperative learning groups enjoyed cooperative activities and obtained more knowledge because cooperative learning improved their relationships with their peers, decreased conflict in the group and enhanced their self-esteem. Also, students in the cooperative learning groups felt more interested in learning, and less anxious, perceiving cooperative learning as a valuable way to effectively increase their knowledge.

\subsubsection{Learning skills and self-esteem}

The cooperative context has been argued to enhance the use of problem-solving, critical thinking and oral communication skills (Johnson, 2003; Adeyemi, 2008), and interpersonal skills (Baker \& Clark, 2010), because students entertain a range of different ideas during their performance of learning tasks (Abrami \& Chambers, 1996). Furthermore, cooperative learning facilitates greater improvement in self-esteem than does competitive (effect size $=$ 0.58 ) or individualistic learning environments (effect size $=0.44$ ) (Johnson \& Johnson, 2005). In some studies (Kilic, 2008; Bertucci et al., 2010), students' self-esteem increased in cooperative situations because students were involved in cooperative efforts. The findings reported above validate the results of other studies (Gillies, 2006; Zain, Subramaniam, Rashid, \& Ghani, 2009; Kose, Sahin, Ergun, \& Gezer, 2010; Thanh-Pham, 2011) which report that cooperative learning promotes more use of higher-level learning skills, more positive cohesion among participants, higher self-esteem in learning and more positive feelings toward the learning tasks. These gains in the cooperative learning groups may be explained by two factors. Firstly, students felt that they achieved more by learning through this method; and secondly there was an improvement in social relations among students (Johnson \& Johnson, 2009). It may therefore be argued that cooperative learning appears to be an effective way to engage students in learning.

The literature reviewed above shows that cooperative learning appears to have a greater likelihood of improving the attitudes of students toward their own learning. However, the review also shows that almost all studies which supported the effectiveness of cooperative learning on student attitude were conducted in the context of western education. The current study adds to the literature by empirically investigating the impact of cooperative learning in a Vietnamese higher education institution. Specifically, it reports the results of an experimental study designed to determine if jigsaw learning is more effective than lecture-based learning in improving attitudes of university students. The participating students were undertaking a Graduate program focusing on Managing Administration and Education (MAE), in the Faculty of Education at An Giang University in Vietnam, where learning is generally perceived to be passive (Director, Doughty, Gray, Hopcroft, \& Silvera, 2006) and the dominant pedagogical method is lecture (MOET, 2009; Harman \& Nguyen, 2010). Even though there is a view that culture determines the learning styles of students (Neuman \& Bekerman, 2000), the benefits of cooperative learning in western contexts found in the literature indicate that this kind of learning may not be culturally-based but contextual. The positive effects of cooperative learning on social, affective and psychological variables, found in the literature, have led to the following primary research question of this study "What do Vietnamese students like and dislike about group work learning?" Specifically, this study will investigate the extent to which Vietnamese students mention the kinds of 
positive factors related to cooperative learning commonly cited in earlier research. These factors include increased social support, both personal and academic, more positive relationships, greater achievement from working with others and teaching others in groups, greater improvement in learning skills and increased self-esteem. Our previous study (Tran \& Lewis, 2012) briefly indicated that students in the treatment group enjoyed cooperative learning for a number of reasons that will be investigated in much greater detail below.

\section{Method}

As noted in our previous report (Tran \& Lewis, 2012), an experimental study was undertaken, using the Pre-test-Post-test Non-equivalent Comparison-Group Design, to test the cause and effect relationship between a treatment variable (jigsaw learning pedagogy) and the outcome variable (achievement in MAE course). The study used a sample of 80 final-year students comprising 32 females and 48 males, from two mathematics classes in the Faculty of Education at An Giang University in Vietnam. The 80 students were matched into two groups of 40, based on the variables of age, gender and GPA scores. In the experimental group of 40 students, there were 24 males and 16 females with a mean age of 21.50 and a mean GPA score of 6.45 , while in the control group of 40, there were 24 males and 16 females with a mean age of 21.53, and a mean GPA score of 6.51. The results (Tran and Lewis, 2012) showed no significant differences between groups' GPA scores or their scores on a content related pre-test.

During the experimental procedure in this study, students in the control group, students learned the MAE content as a result of lecture-based teaching in logical steps, and they worked as a whole class group. The instructor's role was one of information transmitter. The main interaction was between the teacher and the students. The instructor determined the speed of delivery, as he taught the material and decided when questions were to be answered and tests were to be administered. It was the students' responsibility to master the subject and to be ready to do the tests. In the experimental group, the instructor attempted to guide students to learn the MAE content using the jigsaw technique. In this group, the instructor's role was one of learning facilitator. The interactions were between the learning materials and the students, between students, and between students and the teacher. The instructor applied the following eight steps. First, the objectives of the subject matter were identified. Second, the learning materials were organized. Third, ten home groups of four students were formed, and eight jigsaw groups of five were formed from the ten home groups. Fourth, the instructor explained the process. Each unit was divided into four independent subunits and each was given to a different member of a home group. Each student in a home group received a different subunit to study. Each student then read to the other home group members the title of the subunit assigned to him or her, so that all of the group members become acquainted with the sequence of the learning material. Fifth, when students understood the lesson structure, they were asked to move to new groups called jigsaw groups. There were eight jigsaw groups of five students formed from the ten home groups. Sixth, the instructor had students help one another to learn their respective specialist sections. Consequently five students helped one another to learn one of the four subunits, with two groups devoted to each of the four subunits. Seventh, after students had helped each other to learn their learning materials, they were requested to return to their home groups to teach other members what they learned from their experience in the jigsaw groups. Finally, the instructor assessed understanding of the entire unit through students' presentations in front of the whole class. This whole process was repeated six times, once for each unit of work. Throughout the study, both groups were taught by the researcher, an MAE instructor. The experimental group was conducted on Mondays, while the control group was on Tuesdays. Both groups covered the same MAE content and received MAE instruction for the same amount of time in the mornings, and in the same room. All students in both groups participated in one instructional session of 150 minutes per week for each MAE unit over the six weeks. After the treatment, a survey questionnaire was given to the treatment group only, to measure attitudes toward jigsaw learning.

As described in the previous report (Tran \& Lewis, 2012), one closed and two open questions, were given to the treatment group only, to investigate students' attitudes toward jigsaw learning in their MAE unit. The first question assessed students' attitudes, using the alternatives: liked a lot, liked a little, not sure, disliked a little and disliked a lot. The last two open questions permitted students to document why they liked or disliked jigsaw process. To attest to the reliability of the findings which emerged from the narrative account of the two open questions, an auditor (Creswell \& Miller, 2000) was invited to ensure correct interpretations. Data collected from the responses of the forty students to the two open questions on the attitude survey were analyzed qualitatively. An analysis of the content was used to identify themes in students' responses, to develop categories of responses based on common themes, and to tabulate the number and percentage of frequent responses for each category.

\section{Results \& Discussion}

In the previous report (Tran \& Lewis, 2012), the results of the one-way ANCOVA analysis with MAE pre-test scores 
as the covariate found significant differences in MAE post-test scores, and in MAE delay test scores. This analysis showed that students in the cooperative learning group, who perceived their instruction as more cooperative and more student-centered, had higher overall improvement in adjusted scores on the MAE post-test and delay test than did students in the comparison group, when adjusted for pretest scores. As indicated above, this paper utilised a questionnaire assessing the attitudes of all forty students in the treatment group to learning via jigsaw grouping after the treatment. The first question asked students to indicate the degree of enjoyment that they experienced in jigsaw learning. The vast majority of students in the experimental group liked the way they were 'taught'. These survey results are consistent with the student reactions to cooperative learning groups confirmed by other researchers (Mulryan, 1994; Nattiv; 1994, Whicker, et al., 1997; Vaughan, 2002). Inspection of their responses shows that thirty students (77.5\%) liked jigsaw learning a lot, seven students (17.5\%) liked it a little, only two students $(5 \%)$ were not sure whether or not they liked this learning, and no-one disliked it. The post treatment results indicate that students' attitudes towards jigsaw learning are overwhelmingly positive. The results of this study showed that a sample of Vietnamese tertiary students taught by jigsaw learning have positive attitudes towards their own learning and to this kind of learning. This has confirmed that cooperative learning results in more positive attitudes toward learning as reported by Johnson \& Johnson (2005).

For the last two open questions, students were asked why they liked or disliked jigsaw learning. The results of this study showed that most students liked working with others and getting help, discussing and sharing information with others, teaching others, helping one another, and enjoying the jigsaw context. These results are consistent with student responses to cooperative learning reported by other researchers (Mulryan, 1994; Nattiv; 1994, Whicker \& Nunnery, 1997; Vaughan, 2002; Sahin, 2010; Le, 2010; Thanh-Pham, 2011). In addition, students in the treatment group stated that jigsaw learning promoted friendly relationships among participants, and improved their learning skills as well as their self-esteem. These findings clearly support those of several earlier studies which show that cooperative learning groups result in positive relationships among participants (Vaughan, 2002; Johnson \& Johnson, 2005), and enhance learning skills and self-esteem (Lampe, Rooze \& Tallent-Runnels, 1996; Johnson, 2009; Bertucci et al., 2010).

The most frequent response of students (62.5\%) highlighted that they liked working together and getting help from others. The students expressed positive attitudes toward jigsaw learning and enjoyed the group spirit, that they suggested helped them become more attentive to the learning process. For example, one student said "This is the first time I had studied in such a way ... it is much easier to understand learning material when studied in this way. I learned much from working with group members and from receiving help from others in the group. I found that my learning was effective and efficient... It encourages me to be an independent learner. I found that working with other students in groups was more effective than working individually. My learning was more effective when we worked together and helped one another to learn cooperatively" (Subject 1). Similarly, according to another student "I like everything about jigsaw learning. I learned more from working and sharing information with others in my group. I found that all group members were concerned about each other. I am happy because my learning was more effective than I expected. Cooperative learning enables me to develop a deeper understanding of the subject and to hear different perspectives from other students on the things I am learning. I gained more knowledge and developed better learning skills from engaging in cooperative activities when I offered explanations to others or received explanations from others..." (Subject 13). In this study students felt that they learnt and achieved more from working with others and getting help. This factor encompassed the spirit of social support among group members that helped them become attentive in the learning process, as proposed by Slavin (2011). The results of this study showed that students in the treatment group gave and received considerable social support, both personal and academic. Most students in the treatment group believed that working together with other students in groups was more effective and efficient than were their previous experiences of working individually. They also perceived that they gained more knowledge from engaging in cooperative activities and helping one another learn MAE materials cooperatively in groups. The findings of the present study were consistent with the results of Johnson \& Johnson's (2005) study, which showed that cooperative learning promoted greater personal social support than did competitive (effect size $=0.62$ ) or individualistic (effect size $=0.72$ ).

The second most frequently occurring response $(42.5 \%)$ related to discussing and sharing information with other students. This category encompassed the social benefits of group learning as Johnson (2003) found. For example, one student said "To be honest, my learning was more valuable and meaningful than what I had expected from this MAE course because I had many opportunities to discuss and share information with the other students in my group ... With jigsaw learning, during the class, my teacher did not talk much. He asked us to study in groups. This helped me pay more attention to what I was studying" (Subject 8). Another student said "I had more opportunities to 
exchange and share knowledge in my group so I think my learning was very meaningful. I obtained more knowledge because I worked with other group members and received help from others. I paid more attention to learning ... I retained the knowledge and information for a long time" (Subject 14). The majority of students in the cooperative learning group valued the group discussion and information exchange among group members. Students found that their learning was more valuable and meaningful than what they had expected from the MAE course because they had many opportunities to discuss and share MAE information with the other students in groups. They also perceived that during each MAE lesson, when they presented ideas, their group members listened attentively, and asked questions cooperatively and respectfully.

The third most frequently occurring response (22.5\%) referred to the effectiveness of teaching others. For example, one student said "In this MAE course, I found that teaching others helped me learn more. This method gave me the time and opportunity to explore materials, and discuss information with my group members...because the material is divided into several smaller parts. All the group members had to learn their own part and then teach these parts to other group members. It was really helpful to teach others in my group. Teaching others helped me widen my knowledge" (Subject 4). Another student said "In this course, one thing I liked the most was teaching the other members in my group. I became "a teacher" because I had to teach the part which I had learned to the other group members. This helped me broaden my knowledge and retain this knowledge for a long time. Besides, when I faced difficulties in my learning, I asked for assistance from my group members. I found that most group members were responsible for the group's performance. They took care of one another" (Subject 21). As indicated above, students gained more knowledge than they had anticipated through teaching others in groups. This factor was the main technique of cooperative learning (Kagan \& Kagan, 2009). Teaching others helped students obtain more knowledge and promoted greater long-term retention as suggested by Johnson \& Johnson (2006). Students in the treatment group thought that teaching others helped them learn more because it gave them the time and opportunity to explore materials, and discuss information with group members.

The fourth most frequently occurring response (22.5\%) highlighted the extent and usefulness of mutual help among students. For example, one student said "Jigsaw learning promotes mutual concern among students. Jigsaw learning helped me learn more by getting help from others in my group. Jigsaw learning offers more advantages than traditional teaching. Jigsaw learning helped me to be active in exploring learning materials and in constructing knowledge. It helped me become more independent in my learning. I found that in cooperative learning students are involved in an experiment rather than listening to the lecture of the teacher, as in traditional learning" (Subject 6). Another student said "I realized that there is more mutual concern among students when we are in a cooperative learning group. To achieve the shared goals, we had to help one another to learn. I think that all group members were responsible, not only for their learning but also for others' learning. I liked jigsaw grouping very much" (Subject 9). The data obtained from the post-attitude survey showed that students in the treatment group felt that they were able to get help from other group members in learning. This factor also encompassed the social benefits of cooperative learning identified by Johnson (2003) and Slavin (2011). In this study, students in the treatment group recognized that that there was more mutual concern among students when they were in a cooperative learning group. They believed that, to achieve the shared goals, they were responsible, not only for their learning but also for others' learning. They also found that they had an in-depth understanding of the learning materials because the teacher spent more time focusing students on how to learn and how to engage actively in learning, and students spent more time discussing the learning tasks with the other students in the group.

The fifth most frequently occurring response (17.5\%) related to improving learning skills in terms of critical thinking and oral communication. For example, one student said "I found that I had more opportunities to discuss learning materials in groups. This improved my oral communication skills, and encouraged my speaking and reasoning ability. The interaction that occurred during cooperative learning helped to motivate students and stimulate their learning, develop the students' creativity and their ability to work cooperatively. Now I am very confident to ask about any learning issues or to make a presentation in front of the whole class" (Subject 11). Students in the cooperative learning group claimed that they had greater improvement in learning skills in terms of problem-solving, critical thinking and oral communication. They believed that they were interested in the MAE course since discussing the subject matter and exchanging information with other students in groups helped them improve their higher-level thinking skills. Students also perceived that cooperative learning promoted their critical thinking and communication skills through exploring and summarizing MAE materials as well as via explaining and elaborating these to others in groups. This result was consistent with the findings obtained from the study of Johnson \& Johnson (2005) which show that cooperative learning promotes a greater use of higher level cognitive strategies and higher-level thought than competitive (effect size $=0.93)$ or individualistic instruction $($ effect size $=0.97)$. 
An enjoyable learning environment was another frequently endorsed benefit (15\%) of cooperative learning. For example, one student said "I really enjoyed cooperative learning during the six-week MAE course. I felt that I was in a comfortable and supportive learning environment. I did not sit there to receive what the teacher transferred. I had to discuss learning tasks and share information with the group members in my group. My learning happened through reciprocal interaction with others ... this learning makes the learning environment more natural and interactive" (Subject 5). Almost all students in the treatment group perceived their learning environment as very cooperative, and interactive. They also indicated that they really enjoyed cooperative learning during the six-week MAE course because they were in a comfortable and supportive learning environment, in which they had to discuss learning tasks and share information with group members instead of sitting passively to receive what the teacher transferred by lecture The findings of the present study were consistent with the results of Slavin's (2011) study which showed that cooperative learning makes the learning environment more natural, interactive and enjoyable.

The next most common response (of five students, 12.5\%) focused on how cooperative learning creates friendly relationships among students when they work in the groups. For example, one student said "Jigsaw learning promotes friendly relationships among students, and between students and the teacher. It sets up a comfortable learning atmosphere. When I asked something, my friends and the teacher were ready to answer my questions. I really liked this learning" (Subject 12). Students recognized that cooperative learning promotes positive relationships and mutual concern among students in group activities, as well as promotes friendly relationships between students and the teacher. This result confirmed the findings yielded in Johnson \& Johnson's (2009) study which show that cooperative learning promotes more positive relationships among participants than does competitive (effect size $=0.67$ ) or individualistic learning (effect size $=0.60$ ). In this study such positive relationships were associated with the higher achievement of students in the cooperative learning group (Tran and Lewis, 2012), as predicted by Johnson \& Johnson (2006).

Finally, five students (12.5\%) perceived that cooperative learning improves confidence. For example, one student said "In this MAE course, I think that I was more confident because of the jigsaw learning groups. In fact, I never knew I was able to present my ideas or my understanding to my friends until this semester when the MAE teacher applied cooperative learning. Now I am really confident to express and present my opinions and to teach what I know to my group members. I like this style of learning very much. I feel less nervous and more courageous to talk because I am not alone in my group" (Subject 31). Students in the treatment group thought that they were more confident because the MAE teacher had applied cooperative learning. They perceived that they were confident to express and present their opinions to their group members and they felt less nervous and more willing to talk. These gains in the cooperative learning groups may be explained by two factors; Firstly, students felt that they achieved more by learning through this method; and secondly there was an improvement in social relations among students as noted by Johnson \& Johnson (2009). This result was also consistent with the findings of Johnson \& Johnson (2005) which show that cooperative experiences promote greater improvement in self-esteem than do competitive (effect size $=0.58)$ or individualistic (effect size $=0.44)$ experiences.

In general, the students' perceptions in the treatment group indicate that cooperative learning resulted in very positive attitudes toward learning and greater continuing motivation to complete tasks. Further, since students in the treatment group often referred to "more attention", "more independence", "more learning", "more confidence", the implication is that students in the treatment group experienced more positive attitudes toward their learning during cooperative learning than they had previously experienced when engaged in traditional teacher-centered classrooms. These positive attitudes toward cooperative learning resulted from the students' achieving more from working with other students, retaining more knowledge from sharing and teaching others, improving learning skills, facilitating mutual help, and improving in confidence and social relationship among students in an enjoyable learning environment. The results of this study showed that students in the cooperative learning group had positive attitudes toward their learning since they were academically, socially and psychologically successful. The findings of this study are consistent with those of several previous extensive reviews (Bertucci et al., 2010; Johnson \& Johnson (2008). These findings are also consistent with the findings of some recent studies (Whicker \& Nunnery, 1997; Vaughan, 2002; Kose et al., 2010; Zakaria, Chin, Daud, 2010).

These positive responses were well supported by other findings from our previous report (Tran \& Lewis, 2012), which noted that in the treatment group there was higher academic achievement and knowledge retention, (and more centred-student activities) than there was in the control group. The present study appeared to support Johnson \& Johnson's (2009) findings that achievement and attitudes in the cooperative learning context are strongly correlated. Specifically, cooperative learning encourages the achievement of students, which in turn has an impact on attitudes of students. It is not surprising therefore that the students in the treatment group reported more learning in groups, 
helping and teaching each other, discussing the learning material among participants as well as a greater exchange of information than they had experienced in the traditional teacher centered lectures.

However, the results of this study also show that some students disliked permanent groups, uncooperative group members, irresponsible group members, and shy group members, while some students felt left behind in the learning process. Some changes to the instruction were recommended by students. The most common, proposed by three students, was to rotate group members. Other suggested changes focussed on teaching interpersonal and social skills, and explaining both individual and group accountability clearly.

Some students felt left behind (7.5\%), as indicated in the following responses: "I felt lonely and left behind in my group when my group discussed the learning materials. Sometimes, I was passive and only listened to the presentation of other group members. I found that the other members were very excellent at understanding the subject matter, and they solved issues quickly. I did not solve these issues as fast as they did. Thus, I felt that I was dependent on them. I am upset" (Subject 25). "I feel left behind in group activities. All the problems in the subject matter were completely solved by the other group members while I was not able to solve any. I did not make many contributions to my group. Most group members were very active in discussions, while I was passive. I only listened and hardly expressed my own ideas" (Subject 37). Others disliked pre-assigned groups (7.5\%). For example, one student said "I did not like the permanent groups. One group had four members. This is great but group membership should change after each teaching session to allow students to meet new members. I think that this would help students learn better" (Subject 3). Another student said "One thing I did not like was formation of permanent group over the duration of the course. This made me lose motivation for each lesson in my group" (Subject 32). Some students complained about uncooperative group members (5\%). For example, one student said "Jigsaw learning is great. One thing I did not like is that some group members did not really cooperate with us in all group activities in relation to the subject matter. This affected the results of the discussions. We prepared information carefully for discussions, while some members were very careless in their preparation. We focused on discussing and exploring materials, while some members did their own work. They did not accept others' ideas nor did they support each other" (Subject 36). Others cited irresponsible group members (5\%). For example, one student said "the one thing I did not like was that some members in my group were not responsible for their particular part of the learning materials. They did not take their tasks seriously. This made me unhappy. As they lacked individual accountability, my group's achievement was not as good as I expected. At the beginning of the course, the teacher should have explained clearly about individual and group accountability to all participants" (Subject 15). Finally, only one student (2.5\%) expressed concern about shy group members. This student said "I was concerned .... that some group members were too shy to express their own opinions on the issues being discussed. Our learning achievement would have been higher if all group members had actively shared and contributed their ideas... the teacher should have paid more attention to group activities to help these shy group members" (Subject 22).

As explained in our previous paper, the home groups and jigsaw groups were formed before the experiment commenced (Tran \& Lewis, 2012). Although some students found that it was great when one group had four members, they did not like the groups that were pre-assigned and permanent. Some students believed that they would have learned more if members in groups were changed following each teaching session. Mulryan (1994) reports that most teachers and students like the relatively frequent changing of group members. However, if the assertion is accepted that the gradual development of group cohesion enhances group productivity, then frequent changing of group members may impede this group dynamic, and ultimately achievement, as argued by Whicker \& Nunnery (1997). The results of this study showed that two recommendations consistently made by some students were to teach interpersonal and social skills, and to explain both individual and group accountability clearly. This probably relates to the observation that some students in the treatment group did not like uncooperative or irresponsible group members. They perceived that some members in their group were not responsible for their particular part of the learning materials, and not cooperative with others in group as a result of a lack of individual accountability and dysfunctional interpersonal and social skills. Some students claimed that they prepared information carefully for discussions, while others were seen as very careless in their preparation. Students added that they focused on discussing and exploring MAE materials, while others were perceived to do their own work. As described in the previous study (Tran \& Lewis, 2012), all forty students in the treatment group had undergone a six-week training course related to cooperative learning in which interpersonal and social skills, and individual accountability were taught and explained clearly before the experiment commenced. Unfortunately, the training programme involved only six-training sessions. Therefore, some students may not have sufficient involvement in mastering skills and understanding their accountability for learning in groups. This conclusion appears consistent with the suggestions argued by Johnson \& Johnson (2008), which showed that students should have a longer period of time to expose their personal and social skills as well as to recognise the extent of their individual accountability in learning. 
Nevertheless, when students were asked what they disliked about jigsaw learning, they generally said that there was nothing to dislike $(67.5 \%)$, or that they liked it all $(72.5 \%)$. One student however wrote, "At first, I did not like this method because I felt it was really different from what I had learnt from the traditional teaching method, but then I really grew to like this learning because it made the lessons become more interesting and enjoyable. We always discussed and shared the subject matter with other group members" (Subject 14). In summary, the findings of this study showed that a sample of Vietnamese students (in the treatment group) recognized the value of the cooperative learning approach for their own learning. They perceived their instruction as cooperative and more student-centered, and they exhibited positive attitudes toward their learning. These findings were consistent with the comments of Tribe (1994) about cooperative learning in higher education: ". . . most students are quick to see the advantages of group learning methods and will adapt relatively rapidly to a change of approach" (p. 29). It is necessary to note that in the previous study (Tran \& Lewis, 2012), students in both the cooperative learning group and the teacher-centered lecture group noted no difference in the teacher's generic teaching skills (organizing, questioning skill, clarity, pace), his subject knowledge and his attempts to facilitate learning. All were rated highly. Consequently it may be argued that students' attitudes in cooperative learning group are more positive than those they held in traditional lectures only when the teacher is good. It would be interesting, but unethical, to try and determine if the same difference in positivity of attitudes were observed when the teacher was equally poor in both settings.

\section{Conclusion}

The findings of this study revealed evidence that supports the positive impact of cooperative learning on the attitudes of a group of Vietnamese students toward their own learning. In general, these students preferred cooperative learning to the more traditional student-centered approach to which they were commonly exposed. This study also confirmed the argument that higher achievement and positive attitudes in the cooperative learning context are strongly correlated. In our previous study (Tran \& Lewis, 2012) students in the cooperative learning group had greater achievement and knowledge retention than did those in the control group. In the present study, the students in the treatment group reported more learning in groups, more helping and teaching each other, more discussing the learning material among participants as well as a greater exchange of information than they had experienced in traditional teacher-centered classrooms. Despite the fact that all of these students were accustomed to the Confucian-heritage learning culture, or teacher-centered style of learning environment (Harman \& Nguyen, 2010), they could adapt to this new style of learning in six weeks of instruction in an Asian learning context. This finding supports those of some previous studies (Biggs, 1996; Volet \& Renshaw, 1996; Wong, 2004; Le, 2010; Thanh-Pham, 2011) which report that Asian students are highly adaptive in accommodating to the style of teaching and learning they experience in Western educational contexts. It therefore can be argued that learning styles are not culturally-based but contextual.

This study showed that the effectiveness of cooperative learning on students is compatible with the requirements of teaching innovation in VHEI (MOET, 2009). The findings provide Vietnamese teachers with more empirical support for promoting productive changes in teaching methods to improve student learning, and their attitudes toward learning, in the current wave of educational reform in VHEI (NASRV, 2008). To promote the implementation of cooperative learning effectively, both teachers and students in VHEI would need to undergo a training course in this kind of learning, and they should be involved in as much relevant teaching and learning as possible. The procedures used to implement cooperative learning in this study involved the formation of permanent groups for the duration of a six-week course. However the results suggest that this period of time might cause students to lose their motivation to learn effectively, as some students in the treatment group reported. Further studies should therefore rotate groups and change group membership following each lesson. The findings of the present study indicate the positive effects of cooperative learning on Vietnamese students' attitudes toward their own learning, as well as towards the instructional method of cooperative learning. This research was one of the first efforts to apply cooperative learning at the higher education level in a MEA course. It is difficult to demonstrate a generalisable effect on student attitudes in one experiment of short duration. In addition, attitude is something which is abstract and subjective and hence it is difficult to measure changes over a short time. In order to identify radical changes in students' attitudes, a more prolonged and extensive treatment may be needed. The attitudes of students towards cooperative learning can be detected not only by means of questionnaires but also by undertaking observations and interviews, to achieve more conclusive findings. As only a few research studies have investigated the effectiveness of cooperative learning in VHEI, the findings of this study are not sufficient to decide on the optimal use of cooperative learning at all levels of education in Vietnam. A series of further studies on cooperative learning at the primary and secondary levels of Vietnamese education should therefore be undertaken. 


\section{References}

Abrami, P. C., \& Chambers, B. (1996). Research on co-operative learning and achievement: comments on Slavin. Contemporary Educational Psychology, 21(1), 70-79. http://dx.doi.org/10.1006/ceps.1996.0005

Adeyemi, B. A. (2008). Effects of cooperative learning and problem-solving strategies on Junior Secondary School Students' Achievement in Social Studies. Electronic Journal of Research in Educational Psychology, 6(3), $691-708$.

Aronson, E., Blaney, N., Stepan, C., Sikes, J., \& Snapp, N. (1978). The jigsaw classroom. (2rd ed.). Beverley Hills, CA: Sage.

Baker, T., \& Clark, J. (2010). Cooperative Learning- a double edged sword: A cooperative learning model for use with diverse student groups. Intercultural Education, 21(3), 257-268. http://dx.doi.org/10.1080/14675981003760440

Ballantine, J., \& Larres, P. M. (2007). Cooperative learning: a pedagogy to improve students' generic skills? Education and Training, 49(2), 127-137.

Beck, L. L., \& Chizhik, A. W. (2008). An experimental study of cooperative learning in CS1. In Proceedings of the 39th SIGCSE technical symposium on Computer science education (pp. 205-209). New York: ACM. http://dx.doi.org/10.1145/1352135.1352208

Bertucci, A., Conte, S., Johnson, D. W., \& Johnson, R. T. (2010). The impact of size of cooperative group on achievement, social support, and self-esteem. The Journal of General Psychology, 137(3), $256-271$. http://dx.doi.org/10.1080/00221309.2010.484448

Biggs, J. (1996). Western misconceptions of the Confucian-heritage learning culture. In D. A. Watkins \& J. B. Biggs (Eds.), The Chinese Learner: Cultural, Psychological and Contextual Influences (pp. 45-67). Hong Kong: The Central Printing Press.

Cavalier, J. C., Klein, J. D., \& Cavalier, F. J. (1995). Effects of Cooperative Learning on Performance, Attitude, and Group Behaviours in a Technical Team Environment. ETR\&D, 43(3), 61-71.

Creswell, J. W., \& Miller, D. L. (2000). Determining Validity in Qualitative Inquiry. Theory Into Practice, 39(3), 124-130. http://dx.doi.org/10.1207/s15430421tip3903_2

Director, S. W., Doughty, P., Gray, P. J., Hopcroft, J. E., \& Silvera, I. F. (2006). Observations on undergraduate education in computer science, electrical engineering, and physics at select universities in Vietnam (A report presented to the Vietnam Education Foundation by the Site Visit Teams of the National Academies of the United States). Ha Noi: Vietnam [Online] Available: http://www.home.vef.gov/download/Report_on_Undergrad_Educ_V.pdf(April 9, 2009)

Gillies, R. M. (2006). Teachers' and students' verbal behaviors during cooperative and small-group learning. British Journal of Educational Psychology, 76(2), 271-287. http://dx.doi.org/10.1348/000709905X52337

Harman, G., \& Nguyen, T. N. (2010). Reforming teaching and learning in Vietnam's higher education system. In G. Haaland, M. Hayden \& T. Nghi (Eds.), Reforming Higher Education in Vietnam: Challenges and Priorities (pp. 65-86). London: Springer. http://dx.doi.org/10.1007/978-90-481-3694-0_5

Jensen, M., Moore, R., \& Hatch, J. (2002). Cooperative Learning - Part I: Cooperative Quizzes. The American Biology Teacher, 64(1), 29-34. http://dx.doi.org/10.1662/0002-7685(2002)064[0029:CLPICQ]2.0.CO;2

Johnson, A. W., \& Johnson, R. (2002). Cooperative Learning Methods: A meta-analysis. Journal of Research in Education, 12(1), 5-14.

Johnson, D. W. (2003). Social Interdependence: The Interrelationships among theory, research, and practice. American Psychologist, 58(11), 931-945. http://dx.doi.org/10.1037/0003-066X.58.11.934

Johnson, D. W. (2009). Reaching out: Interpersonal effectiveness and self-actualization. (10th ed.). Boston: Allyn \& Bacon.

Johnson, D. W., \& Johnson, F. (2006). Joining Together: Group Theory and group skills. (7th ed.). Boston: Allyn \& Bacon.

Johnson, D. W., \& Johnson, R. (2005). New Developments in Social Interdependence Theory. Genetic, Social, \& General Psychology Monographs, 131(4), 285-358. http://dx.doi.org/10.3200/MONO.131.4.285-358

Johnson, D. W., \& Johnson, R. T. (1989). Cooperation and Competition: Theory and Practice. Edina, MN: International Book Company. 
Johnson, D. W., \& Johnson, R. T. (2008). Social Interdependence Theory and Cooperative Learning: The Teacher's Role. In R. M. Gillies, A. Ashman \& J. Terwel (Eds.), Teacher's Role in Implementing Cooperative Learning in the Classroom (pp. 9-37). New York, U.S.A: Springer. http://dx.doi.org/10.1007/978-0-387-70892-8_1

Johnson, D. W., \& Johnson, R. T. (2009). An Educational Psychology Success Story: Social Interdependence Theory and Cooperative Learning. Educational Researcher, 38(5), 365-379. http://dx.doi.org/10.3102/0013189X09339057

Johnson, D. W., \& Johnson, T. R. (1999). Cooperative Learning and Achievement. In D. Kluge, S. McGuire, D. Johnson \& R. Johnson (Eds.), Cooperative Learning: JALT Applied Materials (pp. 23-37). New York: Greenwood Press, Inc.

Kagan, S., \& Kagan, M. (2009). Kagan Cooperative Learning (1st ed.). San Clemente, CA: Kagan Publishing.

Kilic, D. (2008). The Effects of the Jigsaw Technique on Learning the Concepts of the Principles and Methods of Teaching. World Applied Sciences Journal, 4(1), 109-114.

Killen, R. (2007). Effective Teaching Strategies: Lessons from Research and Practice (4 ${ }^{\text {th }}$ ed.). Melbourne: Thompson Social Sciences Press.

Knight, P. G., \& Bohlmeyer, M. E. (1990). Cooperative Learning and Achievemnt: Methods for Assessing Causal Mechanisms. In S. Sharan (Ed.), Cooperative Learning: Theory and Practice (pp. 1-22). New York: Greenwood Press, Inc.

Kose, S., Sahin, A., Ergun, A., \& Gezer, K. (2010). The effects of cooperative learning experience on eighth grade students' achievement and attitude toward science. Education, 131(1), 169-180.

Lampe, J. R., Rooze, G. E., \& Tallent-Runnels, M. (1996). Effects of Cooperative Learning Among Hispanic Students in Elementary Social Studies. The Journal of Educational Research, 89(3), 187-191. http://dx.doi.org/10.1080/00220671.1996.9941324

Le, T. T. (2010). Infusing Cooperative Learning into An EFL Classroom. English Language Teaching, 3(2), 64-77.

Maceiras, R., Cancela, A., Urrejola, S., \& Sanchez, A. (2010). Experience of cooperative learning in engineering. European Journal of Engineering Education, 36(1), 13-19. http://dx.doi.org/10.1080/03043797.2010.518232

Mengduo, Q., \& Xiaoling, J. (2010). Jigsaw Strategy as a Cooperative Learning Technique: Focusing on the Language Learners. Chinese Journal of Applied Linguistics, 33(4), 113-125.

Ministry of Education and Training of Vietnam [MOET] (2009). Development Strategy from 2009 to year 2020 for the Cause of Industrialization and Modernization of Vietnam. Hanoi: Vietnamese Government.

Mulryan, C. M. (1994). Perceptions of intermediate students' cooperative small-group work in mathematics. The Journal of Educational Research, 87(5), 280-291. http://dx.doi.org/10.1080/00220671.1994.9941255

National Assembly of the Socialist Republic of Vietnam [NASRV] (2008). Education Law, No. 38/2008/QH11-2008. Hanoi: Education Press.

Nattiv, A. (1994). Helping Behaviors and Math Achievement Gain of Students Using Cooperative Learning. The Elementary School Journal, 94(3), 285-297. http://dx.doi.org/10.1086/461767

Neuman, Y., \& Bekerman, Z. (2000). Cultural Resources and the Gap Between Educational Theory and Practice. Teachers College Record, 103(3), 417-484.

Nhu-Le, T. (1999). A Case Study of Cooperative Learning in Inorganic Chemistry Tutorials at the Vietnam National University-Ho Chi Minh City (Master dissertation, University of Simon Fraser, Canada). [Online] Available: http://www.ir.lib.sfu.ca/bitstream/1892/8731/1/b19483041.pdf (March, 19, 2010)

Sahin, A. (2010). Effects of Jigsaw III technique on achievement in written expression. Asia Pacific Education Review, 12(3), 427-435. http://dx.doi.org/10.1007/s12564-010-9135-8

Sharan, S., \& Yaakobi, D. (1981). Classroom learning environment of city and kibbutz biology classrooms in Israel. European Journal of Science Education 3(3), 321-328. http://dx.doi.org/10.1080/0140528810030310

Skinner, B. (1968). The technology of teaching. New York: Appleton-Century-Crofts.

Slavin, R. E. (1996). Research on co - operative learning and achievement: What we know, what we need to know. Contemporary Educational Psychology, 21(4), 43-69. http://dx.doi.org/10.1006/ceps.1996.0004

Slavin, R. E. (2011). Instruction Based on Cooperative Learning. In R. E. Mayer \& P. A. Alexander (Eds.), Handbook of Research on Learning and Instruction (pp. 344-360). New York: Taylor \& Francis. 
Thanh-Pham, T. (2010a). Group Composition of Cooperative Learning: Does Heterogeneous Grouping Work in Asian Classrooms? International Education Studies, 3(3), 12-19.

Thanh-Pham, T. (2010b). Implementing a Student-Centered Learning Approach at Vietnamese Higher Education Institutions: Barriers under Layers of Casual Layered Analysis (CLA). Journal of Futures Studies, 15(1), 21-38.

Thanh-Pham, T. (2011). An Investigation of Perceptions of Vietnamese Teachers and Students toward Cooperative Learning. International Education Studies, 4(1), 3-12.

Thomas, E. J. (1957). Effects of facilitate role interdependence on group functioning. Human Relations, 10, 347-366. http://dx.doi.org/10.1177/001872675701000404

Tran, V. D., \& Lewis, R. (2012). Effects of Cooperative Learning on Students at An Giang University in Vietnam. International Education Studies, 5(1), 86-99. http://dx.doi.org/10.5539/ies.v5n1p86

Tribe, D. M. R. (1999). An overview from higher education. In L. Thorley \& R. Gregory (Eds.), Using group-based learning in higher education (pp. 25-31). London: Kogan Page.

Vaughan, W. (2002). Effects of Cooperative Learning on Achievement and Attitude Among Students of Color. The Journal of Educational Research, 95(6), 359-364. http://dx.doi.org/10.1080/00220670209596610

Volet, S., \& Renshaw, P. (1996). Chinese students at an Australian university: Adaptability and continuity. In D. A. Watkins \& J. Biggs (Eds.), The Chinese Learner: Cultural, Psychological and Contextual Influences (pp. 205-220). Hong Kong: The Central Printing Press.

Whicker, K. M., Bol, L., \& Nunerery, J. A. (1997). Cooperative learning in the Secondary Mathematics Classroom. The Journal of Educational Research, 91(1), 42-48. http://dx.doi.org/10.1080/00220679709597519

Wong, J. K. (2004). Are the Learning Styles of Asian International Students Culturally or Contextually Based? International Education Journal, 4(4), 154-166.

Yager, R. E. (2000). The Constructivist Learning Model. The Science Teacher, 67(1), 44-45.

Yamarik, S. (2007). Does cooperative learning improve student learning outcomes? (Research in Economic Education)(Report). The Journal of Economic Education, 38(3), 259-277. http://dx.doi.org/10.3200/JECE.38.3.259-277

Zain, Z. M., Subramaniam, G., Rashid, A. A., \& Ghani, E. K. (2009). Teaching Students' Performance and Attitude. Canadian Social Science, 5(6), 92-102.

Zakaria, E., Chin, L. C., \& Daud, Y. (2010). The Effects of Cooperative Learning on Students' Mathematics Achievement and Attitude toward Mathematics. Journal of Social Sciences, 6(2), 272-275. http://dx.doi.org/10.3844/jssp.2010.272.275 